\title{
ALLELOPATHIC EFFECTS OF Cyperus rotundus L. AND Cynodan dactylon L. ON GERMINATION AND GROWTH RESPONSES OF LETTUCE (Lactuca sativa)
}

\author{
HASL Jayasinghe* and ANR Weerawansha
}

\author{
Uva Wellassa University, Sri Lanka
}

\begin{abstract}
This study was conducted to investigate the allopathic effects of Cyperus rotundus and Cynodan dactylon (L.) extracts on seed germination and seedling growth characters of lettuce (Lactuca sativa). Four concentrations (5, 10, 15 and $20 \%$ ) of whole plant aqueous extracts of both weeds were tested for assessing their allelopathic effect on seed germination and seedling growth of Rapido 344 lettuce variety. This study was conducted at Biology Laboratory of Uva Wellassa University, Sri Lanka in 2014 and experimental units were petri dishes in depths and diameters of 2 and $5 \mathrm{~cm}$, respectively. The shoot and root length, dry weight, germination percentage were measured. The experimental results revealed that all the concentrations of both the weed extracts had inhibition effect on germination percentage, shoot $\&$ root length and dry weight of lettuce. The inhibitory effect of the extracts was concentration dependent. However, at $5 \%$ of C. dactylon extract did not significantly affect on seed germination and growth of seedlings. The highest degree of growth inhibition was observed in $20 \%$ of both weed extracts.
\end{abstract}

Keywords: Cyperus rotundus, Cynodan dactylon, lettuce, allelopathy

\section{INTRODUCTION}

The lettuce (Lactuca sativa) comes under the family compositae. It is one of the most important vegetable crops in the world. In Sri Lankan context lettuce is not cultivated as a monocrop. It is always mixed with other crops which ultimately result in low productivity. The quality, too is poor due to poor management practices. Specially weeds are the most severe and widespread biological constraint to lettuce as experienced in lettuce grown cultivars in Sri Lanka (Department of Agriculture, 2010).

Weeds are undesirable plants which compete with main crops in the growth media for nutrients, moisture, space, light and hamper the healthy growth ultimately reducing the growth and yield both qualitatively and quantitatively. Allelopathy is a harmful effect generated as a result of the secretion of biochemical substances by a given plant on a receiver plant (Rice, 1984). Allelopathy is of two types, one is true allelopathy and other is functional allelopathy.
The true allelopathy is the release of substances that are toxic in the form in which they are produced in the plant. Functional allelopathy is the release of substances that are toxic or a result of transformation by micro-organism (Wittekar, 1999). According to Muller (1969) the term allelopathy refers to the overall influence of one plant on another, due to the chemical compounds being added to the environment. The phenomenon of allelopathy has reviewed a wide attention in the past three decades in Sri Lanka.

Cyperus rotundus L. (Family Cyperaceae), also known as purple nutsedge or nutgrass, is a common perennial weed with slender, scaly creeping rhizomes, bulbous at the base and arising singly from the tubers which are about 1-3 cm long. Cynodon dactylon (Family: Poaceae, Arugampullu in Tamil, Dhub in Hindi, Bermuda grass in English). A creeping herb rooting at the joints with smooth upward stem. Previous phytochemical studies on C. rotundus

Corresponding Author: *sadeekaLJ@gmail.com 
revealed the presence of alkaloids, flavonoids, tannins, starch, glycosides and furochromones, and many novel sesquiterpenoids (Xu et al., (2008); Sayed et al., (2007) and Jeong et al., (2000)).

C. dactylon contains beta sitosterol, beta-carotene, vitamin $\mathrm{C}$, palmitic acid, and triterpenoids. Alkaloids like ergono- vine, ergonovivine (Ravindra, 2003).

Allelopathy can be the most effective form of interference during the juvenile stages of the susceptible plants and allelopathic interactions play a major role in the determining the distributions of plants in nature and yield of different crops (Fisher, 1980). Hence, in the present investigation an attempt has been made to study the allelopathic effect of Cyperus rotundus $\mathrm{L}$. and Cynodan dactylon $\mathrm{L}$. on seed germination and seedling growth lettuce.

\section{METHODOLOGY}

The experiment was conducted in the Biology Laboratory at Uva Wellassa University, Sri Lanka. The experiment was performed with four different concentrations of extract of Cyperus rotundus L. and Cynodan dactylon (5, 10, 15, $20 \%$ ) and a control $(0 \%)$. Each treatment including control was replicated four times. The preparation of aqueous weed extracts and germination studies were followed as per the methods of Padhy et al. (2000) and Bhatt and Chauhan (2000). The collected fully matured whole parts of Cyperus rotundus L. and Cynodan dactylon L. were air dried, ground to fine powder and extracted in water. $20 \mathrm{~g}$ of ground weed material was soaked in $1 \mathrm{~L}$ of distilled water and kept 48 hours at room temperature with occasional shaking. The infusion was decanted and filtered through three layers of Whatman number1 filter paper. From this weed extracts of $20 \%$, further dilutions of 15,10 and $5 \%$ were prepared with distilled water. The test units were petri dishes (diameter $4 \mathrm{~cm}$ and depth $2 \mathrm{~cm}$ ). Next, $10 \mathrm{ml}$ of each extract was added to each sterilized petridish and ten seeds of Rapido 344 lettuce seeds were placed. After that petri dishes were placed in the growth room in completely darkness both day and night at $25{ }^{\circ} \mathrm{C}$. In order to neutralize evaporation and changes to the various extracts, the caps of the petri dishes were closed firmly. There were two steps in the experiment. The effect of
Cyperus rotundus and Cynodan dactylon on germination, shoot length, root length and dry weight of lettuce seedlings was examined separately as two steps. Each step consisted with five treatments including control. There were four replicates in each treatment. Germination percentage, shoot length, root length, dry weight were measured. Morphological parameters were recorded on $15^{\text {th }}$ day after sowing. Seeds were considered germinated when the emergent root reached $2 \mathrm{~mm}$ length. Germination percentage was calculated using the following formulas (Eq. 1) (Mostafavi, 2011). The mean data was statistically analyzed by ANOVA followed by Duncan's multiple Significant Difference test (DMRT) at $\mathrm{P}<0.5 \%$.

$\mathrm{GP}=\mathrm{SNG} / \mathrm{SNO} \times 100 \%$

Where: GC is germination percentage, SNG is the number of germinated seeds, and SNO is the number of experimental seeds with viability.

\section{RESULTS AND DISCUSSION}

Aqueous weed extracts of $C$. rotundus and $C$. dactylon caused a significant inhibition on the germination of lettuce seeds over control. The intensity of inhibition differed depending upon the concentration and weed species. As the concentration of the weed extracts increased the degree of inhibition on germination percentage was increased and the extracts of both the weed species significantly affected the germination percentage of lettuce more at their higher concentration $(20 \%)$. As the concentration increased, germination percentage, shoot length, root length and dry weight of lettuce seedlings decreased (Table 1).

These results are similar to the finding of Verma et al. (2002), that found the extracts of $C$. rotundus adversely inhibited the seed germination, seedling growth and biomass production of Brassica and tomato. Mandal et al., (2005), found that the higher concentrations of Populus deltoids plant extract were adversely inhibited germination, seedling growth and reduction in the content of sugar, proteins in three varieties of green gram. The reduction in the seedling growth and biomass may be due to imbalance in water uptake or osmotic balance of the tissues for germination and growth (Blum et al., 1999). 
Table 1: Germination percentage, shoot length, root length and dry weight of lettuce seedlings exposed to aqueous extracts of Cyperus rotundus and Cynodan dactylon.

\begin{tabular}{lllllllll}
\hline $\begin{array}{l}\text { Extract } \\
\text { Concentra } \\
\text { tions }(\%)\end{array}$ & \multicolumn{2}{l}{ Germination $(\%)$} & \multicolumn{2}{l}{ Shoot Length $(\mathrm{cm})$} & \multicolumn{2}{l}{ Root Length $(\mathrm{cm})$} & Dry Weight $(\mathrm{g})$ \\
\cline { 2 - 10 } & $\begin{array}{l}\text { Cyperus } \\
\text { rotundus }\end{array}$ & $\begin{array}{l}\text { Cynodan } \\
\text { dactylon }\end{array}$ & $\begin{array}{l}\text { Cyperus } \\
\text { rotundus }\end{array}$ & $\begin{array}{l}\text { Cynodan } \\
\text { dactylon }\end{array}$ & $\begin{array}{l}\text { Cyperus } \\
\text { rotundus }\end{array}$ & $\begin{array}{l}\text { Cynodan } \\
\text { dactylon }\end{array}$ & $\begin{array}{l}\text { Cyperus } \\
\text { rotundus }\end{array}$ & $\begin{array}{l}\text { Cynodan } \\
\text { dactylon }\end{array}$ \\
\hline Control & $98 \mathrm{a}$ & $98 \mathrm{a}$ & $0.9 \mathrm{a}$ & $1.2 \mathrm{a}$ & $1.5 \mathrm{a}$ & $1.2 \mathrm{a}$ & $0.08 \mathrm{a}$ & $0.07 \mathrm{a}$ \\
\hline 5 & $80 \mathrm{~b}$ & $85.5 \mathrm{ab}$ & $0.5 \mathrm{ab}$ & $1.0 \mathrm{a}$ & $0.7 \mathrm{~b}$ & $1 \mathrm{ab}$ & $0.05 \mathrm{~b}$ & $0.06 \mathrm{a}$ \\
\hline 10 & $52.5 \mathrm{c}$ & $75 \mathrm{~b}$ & $0.3 \mathrm{ab}$ & $0.7 \mathrm{~b}$ & $0.5 \mathrm{~b}$ & $1 \mathrm{ab}$ & $0.01 \mathrm{c}$ & $0.04 \mathrm{~b}$ \\
\hline 15 & $33.3 \mathrm{~d}$ & $48.4 \mathrm{c}$ & $0.1 \mathrm{~b}$ & $0.7 \mathrm{~b}$ & $0.3 \mathrm{bc}$ & $0.8 \mathrm{bc}$ & $0.005 \mathrm{~d}$ & $0.03 \mathrm{~b}$ \\
\hline 20 & $15.5 \mathrm{e}$ & $25 \mathrm{~d}$ & $0 \mathrm{c}$ & $0.4 \mathrm{ab}$ & $0.1 \mathrm{c}$ & $0.5 \mathrm{c}$ & $0.001 \mathrm{e}$ & $0.01 \mathrm{c}$ \\
\hline
\end{tabular}

*Statistically, there is no significant difference among the means with the same letter in each column in Duncan's test $(\mathrm{p}=5 \%)$

The inhibitory effects may be due to the presence of higher amounts of growth inhibitory substances in the tuber extracts that were released during extraction. The differential degree of inhibitory $(5,10,15$ and 20 $\%)$ effect on the growth of lettuce may be due to the presence of various allelochemicals at different level in both the weed extracts. The presence of inhibitory chemicals in higher concentrations of the extract might be the reason for differential behavior of the extracts and causing maximum reduction in growth of the seedlings. Phytotoxicity of allelochemicals present in the weed extracts might be caused synergistic activity on the germination and growth of rice seedlings rather than single chemical.

\section{CONCLUSIONS}

The highest germination percentage and maximum shoot \& root length and dry weight were achieved from the control treatment (no extract). The statistically observed significances are evident for the inhibitory effects of Cyperus rotundus and Cynodan dactylon on the growth of Rapido 344 lettuce variety.

\section{REFERENCES}

Bhatt, B.P. and Chauhan, D.S. (2000). Allelopathic effects of Quercus spp.on crops of Garhawal Himalaya. Allelopathy Journal, 7(2): 265-272

Blum, U., Shafer, S.R. and Lehman, M.E. (1999). Evidence of inhibitory allelopathic interactions involving phenolic acids in field soils: concepts vs. an experimental model. Critical Reviews in Plant Sciences.18: 673-93.
Department of $\quad$ Agriculture. 2010. http://www.meteo.gov.lk/index.php?lang=en Accessed in September 2015).

Fisher, R. F. (1980). In "Plant disease"- Anadvance Treatise (F.G. Horrfall and E.B. Cawling, Eds.,) Academic press, New York. 313.

Jeong, S.J. Miyamoto, T., Inagaki, M., Kim, Y.C., Higuchi, R. Rotundines, A.C. (2000). Three novel sesquiterpene alkaloids from Cyperus rotundus. Journal of Natural Products, 63: 673-675.

Mandal, M.P., Das, D.K. and Singh, A.K. (2005). Impact of leaf extract of Populus deltoids Marsh. on germination and seedling growth of green gram (Vigna radiata L.). Allelopathy Journal, 16(2) 317322.

Mostafavi, K., Sadeghi Geive, H., Dadresan, M. and Zarabi, M. (2011). Effects of drought stress on germination indices of corn hybrids (Zea mays L.). International Journal of Agriculture Science, 1(2):1018.

Muller, C.H. (1969). Allelopathy as a factor in ecological process. Vegetation, 18: 348-357.

Padhy, B., Patinaik, P.K. and Tripathy, A.K. (2000). Allelopathic potential of Eucalyptus leaf litter leachates on germination and seedling growth of finger millet. Allelopathy Journal, 7: 69-78.

Rao, V.S. (1983). Principles of Weed Science. Oxford and IBH Publishing Co. New Delhi, India.

Raut, N.A. and Gaikwad, N.J. (2006). Antidiabetic activity of hydroethanolic extract of Cyperus rotundus in alloxan induced diabetes in rats. Fitoterapia, 77:585-588.

Ravindra S. (2003). Medicinal plants of India an Encyclopedia, Daya Publishing House, New Delhi, 79-80. 
Rice, E.L. (1984). Allelopathy, seconded. Academic press Inc, Orlando, FL, 422.

Sayed, H.M., Mohamed, M.H., Farag, S.F., Mohamed, G.A., Proksch, P.A. (2007). New steroid glycoside and furochromones from Cyperus rotundus L. Nat. Prod. Res. 21: 343-350.

Verma, R., Rao, P.B. and Rawat, Y.S. (2002). Allelopathic effects of certain weed extracts on seed germination of ten varieties of the genus Brassica. Nature and Biosphere, 7(1-2):26-3.
Whittaker, R. H. (1999). In Chemical Ecology (E. Sondheimer and J. B. Simeone, eds.). Academic Press, New York. 43-70.

Xu, Y. Zhang, H., Yu, C., Lu, Y., Chang, Y., Zou, Z. (2008). Norcyperone, a Novel Skeleton Norsesquiterpene from Cyperus rotundus L. Molecules, 13, 2474-2481. 